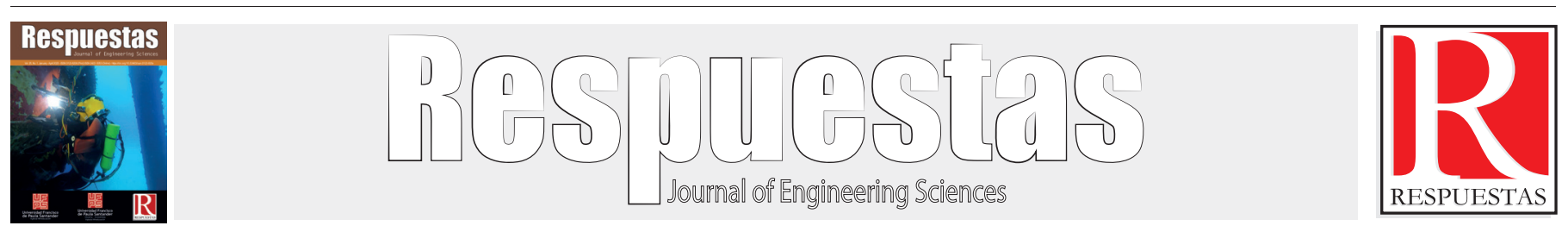

Original Article

https://doi.org/10.22463/0122820X.2431

\title{
Impact of engineering fundamentals on Colombian entrepreneurship
}

\section{Incidencia de los fundamentos de ingeniería en el emprendimiento colombiano}

Hugo Fernando Castro-Silva ${ }^{1}$, Fernando Rodríguez-Fonseca ${ }^{2 *}$, Yamith Alfonso Martínez-Chaparro ${ }^{3}$

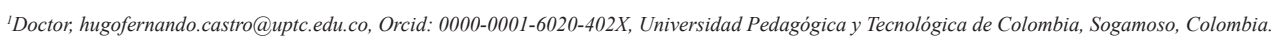

2"Magister, fernando.rodriguez@uptc.edu.co, Orcid: 0000-0002-5972-7496, Universidad Pedagógica y Tecnológica de Colombia, Sogamoso, Colombia.

${ }^{3}$ Magister, yamith.martinez@uptc.edu.co,Orcid: 0000-0002-6885-4366, Universidad Pedagógica y Tecnológica de Colombia, Sogamoso, Colombia.

How to cite: H.F Castro-Silva, F. Rodríguez Fonseca, Y.A Martínez-Chaparro, "Impact of engineering fundamentals on Colombian entrepreneurship". Respuestas, vol. 25 , no. 1 , pp. $138-146,2020$.

Received on July 1, 2019; Approved on November 9, 2019

\begin{tabular}{ll}
\hline ABSTRACT \\
\hline Keywords: & $\begin{array}{l}\text { This paper presents the results of an empirical research related to the personal factors that influence the } \\
\text { disposition of Colombian engineers towards entrepreneurship in their area of training. In order to fulfill this } \\
\text { purpose, a quantitative and correlational research has been implemented, with a methodology similar to that } \\
\text { of related studies in other geographical areas such as Europe and Asia. By means of a factorial analysis, it } \\
\text { entrepreneurship, } \\
\text { entrepreneurial spirit, }\end{array}$ \\
$\begin{array}{l}\text { was possible to purchase the efficiency of the information collection instrument to measure key issues of } \\
\text { the study such as the disposition towards entrepreneurship, leadership, creativity, disposition to perform } \\
\text { professionally as an employee, creativity and intelligence. Confirmatory factor analysis was used to examine } \\
\text { the fit of the model measuring the variables, and correlation models and structural equations were used to } \\
\text { examine the relationships between the variables. The empirical evidence of this research allows us to affirm } \\
\text { that for the population under study there is a significant correlation between entrepreneurship and factors } \\
\text { related to the engineer's personality, but not to creativity and intelligence }\end{array}$
\end{tabular}

\section{RESUMEN}

Palabras clave:

En este escrito se presentan los resultados de una investigación empírica relacionada con los factores personales que influencian la disposición de ingenieros colombianos hacia emprendimientos en su área de formación. Para cumplir con este propósito se ha implementado una investigación cuantitativa y correlacional, con una

Monitoreo Ambulatorio, Electrocardiograma, Procesamiento de Señales, Arritmias cardíacas. metodología similar la de estudios relacionados en otras áreas geográficas como Europa y Asia. Mediante un análisis factorial se pudo comprar la eficiencia del instrumento de recolección de información para medir temas clave del estudio como la disposición hacia el emprendimiento de iniciativas empresariales, el liderazgo, la creatividad, la disposición a desempeñarse profesionalmente como empleado, la creatividad y la inteligencia. Se utilizó un análisis factorial confirmatorio para examinar el ajuste del modelo de medición de las variables y se emplearon modelos de correlación y ecuaciones estructurales para examinar las relaciones entre las variables. Las evidencias empíricas de esta investigación permiten afirmar que para la población objeto de estudio que existe correlación significativa entre espíritu emprendedor con factores relacionados con la personalidad del ingeniero, pero no con la creatividad y la inteligencia

\section{Introduction}

Entrepreneurship has been highlighted as a fundamental element for the development of the countries and in the planning of approaches of education programs. Entrepreneurship has also been defined as the mental model and process of creating and developing an economic activity combining, risk with creativity and/or innovation [1] - [4]. This suggests that an entrepreneur is characterized by his propensity to risk, creative thinking and ability to make the innovations he is able to propose, both for new companies and existing ones.

The concept of entrepreneurship has been integrated several dimensions, such as the use of available resources in innovative ways Schumpeter, 1934 cited in [5], to

*Corresponding author.

E-mail Address:rodriguez@uptc.edu.co (Fernando Rodríguez Fonseca) 
undertaking in a calculated manner activities that carry with them uncertainty and risk [6], to maintain a proactive search behavior [7]; and being a discrete event based on the autonomous search for innovative opportunities [8]; involving again competences of coping with risk and innovation.

In this regard, [9] has proposed competitions for an entrepreneur that are related to aspects, such as 1) associated behaviors or day-to-day behaviors, among which may be cited, among others, the following: Transform events into opportunities, have convening power, transform their context from innovative ideas, be a role model, have communication skills, anticipate events and act to turn them to their advantage, respect laws and regulations and 2) Character attributes such as dynamism and perseverance.

In this same sense, [10], has identified that the most important characteristics that a leader-entrepreneur must meet are: be honest, be visionary, know how to conform and work in teams, make decisions, know how to structure business plans and monitor the environment properly. In addition, they make reference to different styles of leadership within which the entrepreneur-leader moves and establish the style that would most contribute to the achievement of the objectives and the development of their organizations.

Despite the above, the need and importance of a more integrative perspective of the concepts of leadership, creativity, personality factors and entrepreneurship that aims to examine entrepreneurial thinking within existing organizations has been raised [5], [11], [12].

By exploring an integration approach between leadership and entrepreneurship you can find jobs like [12]) which focuses on determining if the research and theory of entrepreneurship can be integrated into a more traditional area such as leadership and considers the proposals of [13] regarding the profile of entrepreneurs and owners of small businesses contain five basic attributes such as: the propensity to risk, the need for achievement, the need for autonomy, the need to maintain control of their lives and self-sufficiency.

The same job [12] proposes a model of entrepreneurial leadership within companies and suggests based on the literature review that many of the foundations used in the area of entrepreneurship are part of the theory of leadership and that therefore entrepreneurs are leaders within a context specific. Therefore, an approach can be conceived that contemplates within the leadership several types of entrepreneurs, with special characteristics.

Under this orientation, the contributions of [5], which define a type of intra- Business entrepreneurial leadership as one that generates visionary scenarios and uses them to motivate and mobilize a group of participants committing them to the creation of strategic value for an organization; for which four conditions are required: 1) the presence and effective communication of a business vision; 2) promote entrepreneurial initiative and support the innovation process, such as those related to the design, development and marketing of new products; 3 ) generate or secure resources and knowledge for business efforts and 4) to facilitate the generation and continuous exploration of ideas.

Addressing the issue of personality and its influence on the willingness of engineers to undertake entrepreneurial initiatives, in literature you can find different theories related to the concept of personality, such as [14], for whom the personality is the set of mental functions that allow a person to adapt himself, others, the community and the environment in which he develops his activities. Or Kalat, cited in [3] who proposes that the personality is a mixture of individual behaviors and influences of the environment that makes an individual different from another, the personality grows, evolves and changes constantly throughout life. Likewise, for [3] personality is defined as the singularity that makes each human being different from another, this difference is the result of internal and external factors presented throughout life. On the basis of the above, it can be suggested that the personality is made up of a series of behaviors or individual characteristics that are the product of genetics or inheritance as well as the influences of the environment and that define that an individual is different from another. In the field of entrepreneurship research, it has been proposed that these differences and other factors greatly influence the propensity to undertake, this issue is addressed in this research.

In relation to the determining factors of entrepreneurial activities, the scientific literature offers different 
approaches ranging from multidisciplinary to specific focused on the personality of the entrepreneur. From a multidisciplinary approach, it is considered that the ability to undertake is influenced by various factors from various sciences such as economics, psychology and sociology according to Gartner, 1990, cited in [15]. Consistent with this approach, are the ideas of [16], related to the process of creating companies, has an interdisciplinary approach taking into account that it should consider the legal framework, the analysis of the factors of the dynamics of the economic sectors in which the company is going to develop, the market conditions, the financing options and, finally, also the personal and behavioral attributes of the entrepreneur.

While from an economic perspective it is stated that entrepreneurship tries to reform the pattern of production by exploiting an unproven technical possibility using available resources in innovative ways, which is not easy as the entrepreneur faces a different economic function and why the environment refuses to finance or buy a new idea [5]. Within this same approach we can locate the work of [17] with his theory of the entrepreneur, where the entrepreneur is an individual who is alert to the opportunities that exist in the market and uses them by implementing their business initiative; although [18], it frames the theory of [17] within a psychological approach, which is going to be discussed later, alluding that its key element is a specific personal characteristic of the entrepreneur that distinguishes it from other individuals: its ability to identify and take advantage of the business opportunities offered by the environment.

On the other hand, there are some approaches that have focused on the personal characteristics of the entrepreneur, such as those identified in [18] that are presented below: 1) The psychological approach, represented by the Theory of Personality Traits enunciated by [19], establishes that the psychological profile that defines the people who approach business initiatives is different from the others; 2) While the managerial approach, locate the works of [20] where they defend the position that the achievement of entrepreneurial success of an initiative, depends on the level of confidence of the entrepreneur individual obtained thanks to the accumulation of skills, knowledge and experiences acquired and 3) the approach that sustains that the entrepreneurial activity comes from a rational process influenced by the academic formation, experience and skills necessary to create and manage an entrepreneur's company [21].

Several studies have been developed in different countries focused on empirically determining, with different methods and populations, if the personality traits determine the propensity to undertake. As a case of the research of [15] who based on the analysis of statistically significant differences in variables related to personality traits, between individuals who decide to undertake a business creation activity and those who decide not to do so, elaborate in a general way a profile of the Spanish entrepreneur, which includes: 1) not being afraid of failure, 2) knowing how to identify good business opportunities in the environment, 3) considering owning the knowledge and skills necessary to create and managing a new business, and 4) recognizing having personally met some entrepreneur in the past years. However, according to the same authors, it seems pertinent also to take into account certain particularities of the environment in which the process of creating companies is developed.

On the other hand, in the study developed in Austria by [22], it is determined that emotional stability and independence seem to promote 1) the value (selfconfidence) to take reasonable risks in the work to try new ways of providing goods and services and 2) the generation of well-coordinated, flexible and persistent actions for the successful achievement of the objectives. They are proposed as key factors in entrepreneurship, personality structure, motivations and interests.

Under this same perspective, [3] conducted a study aimed at students graduates of the University of Cipruta in Indonesia, focused on determining the correlation of three personal characteristics perceived as key to entrepreneurial activity such as creativity, intelligence and personality. The empirical evidences of the study allowed to determine that there is a significant correlation between entrepreneurship and personality, but not with creativity and intelligence.

While in Latin America, specifically in Mexico, when analyzing the personality traits of influence in the entrepreneurial behavior of 53 franchisees of convenience stores, it is concluded that the differentiating characteristics of these entrepreneurs versus those that are not, include 1) the high internal control of the business activity and 2) the propensity to risk, while in the variable need of achievement no significant differences were 
found for the two groups considered. [2]. [3].

In this sense, in the research conducted by [23] in the United Kingdom, it is concluded that people actually differ in their tendencies and abilities to participate in entrepreneurship activities and that these differences are explained in an important way by some elements of intelligence emotional and by the general and fundamental beliefs that individuals have of themselves. Within this same field research on individual differences and entrepreneurship, [24] studied the behavior of Swedish twins and their results demonstrated the importance of genetics and the environment as shared factors to predict the propensity of men and women to undertake business initiatives.

All these investigations suggest that elements of the personality such as propensity to risk, self-control, emotional stability, independence, not being afraid of failure and knowing how to monitor the environment to identify opportunities, really influence entrepreneurship. These elements can be part of the individual personalities thanks to genetics or lived experiences.

The study of entrepreneurship, presents solid theoretical approaches, backed by empirical evidence of studies conducted in different countries, which allow to consolidate the idea of personality directly influences the propensity of individuals to be entrepreneurs, establishing that the creation of a company is a question of the personality structure of the entrepreneur. However, considering other approaches such as those of [25], [26], [16] and [15], the factors that influence the entrepreneurial spirit include, in addition to the personal and behavioral attributes of the entrepreneur, other elements such as education, experience, the skills to create and run a company, the skills to monitor the opportunities presented by the environment and to take advantage of them by analyzing the institutional framework, market factors, financing and other environmental influences.

Therefore, it is proposed that personality is a fundamental condition but not sufficient to explain entrepreneurship. In this order of ideas, one should not reduce the analysis of entrepreneurship to purely personality factors and it is suggested to group the factors that influence the propensity to undertake of people and the chances of success of their initiatives in two dimensions, the first internal one, related to the individual - personality and education - and the second external one related to the environment in which the entrepreneur develops - economic and social conditions -. This research is aimed at establishing if for Colombian engineers, a significant influence is found between factors associated with personality and their willingness to undertake entrepreneurial initiatives in their area of performance.

\section{Materials and methods}

Considering that the different variables considered in the study related to the willingness to undertake entrepreneurial initiatives by the engineers that make up the target population, leadership, creativity, the willingness to perform professionally as an employee, creativity and intelligence have been operationalized On a scale of measurement and through the analysis of data, it is sought to establish if there are significant relationships between a dependent variable and other dependent ones, this research is of a quantitative, exploratory and correlational type [27].

The population defined for this study is made up of engineers graduated from the "Universidad Pedagógica y Tecnológica de Colombia" in the different areas of knowledge and by students of the last semesters of the engineering careers of the same university. The design of the data collection instrument is an adaptation of the instrument used by [28] in which the variables of interest have been decomposed into 65 questions measured on a five-point Likert scale. The first section of the questionnaire collects sociodemographic data of the engineer participating in the study. The second section is dedicated to measuring the intention or not to undertake a business initiative. The third section of the questionnaire is dedicated to measuring the intention of the participant to develop professionally as an employee in a company or to continue studying with a view to improving their professional performance. Finally, the fourth section of the questionnaire is focused on identifying factors of the personality of the engineer, their characteristics of leadership, creativity and intelligence.

A pilot study was carried out in which 96 graduates and university engineering students participated. The composition of the participants was $58 \%$ women and $42 \%$ men; $92 \%$ students in the last semester and $8 \%$ graduates; the average age was 22.2 years, with standard 
deviation of 2.81 years. The pilot study made it possible to improve the wording of some of the questions in the questionnaire. The data obtained from the pilot study were made an exploratory factor analysis and an analysis of the Cronbach alpha index. The results of these two analyzes allowed confirming the validity of the information collection instrument, in that related to the questions or variables are grouped into factors that directly reflect the interests of measuring the willingness to undertake a business initiative, the willingness to perform professionally as an employee and those related to personality trait factors.

Taking into account that the population under study is large, the size of a representative sample was calculated. A simple random sampling is applied to obtain a sample size of 270 engineers resulting from the recommendations of [29] for a scenario of maximum variability, using the equation "(1)":

$$
n=\frac{Z_{\alpha *}^{2} * * q}{e^{2}} .
$$

Where:

$p=q=0.5$ correspond to the probability of success and failure respectively

$\alpha$ or level of significance of $5 \%$

$Z$ value associated with the normal distribution corresponding to the level of significance e or maximum estimation error of 0.05

\section{Results an analysis}

The first activity of data analysis was the filtering in order to identify extreme values and double answers to some of the 65 questions that make up the questionnaire. Regarding the demographic analysis of the sample, we have: 1) $57 \%$ are men and $43 \%$ are women; 2) $77 \%$ correspond to engineering students of last semesters and $23 \%$ to graduate engineers; 3) $36 \%$ of the participants have work experience and $64 \%$ have no experience; 4) $18 \%$ have participated with a business initiative in a seed capital fund in institutions such as the National Apprenticeship Service of Colombia (SENA) and 32\% declare that they intend to start their own business; 5) $14.8 \%$ of the participants reported having work experience on their own account or owning a small or medium business and; 6) The breakdown of participants by academic discipline was as follows; $21 \%$ industrial engineering, $16 \%$ systems engineering, $14 \%$ civil engineering; $13 \%$ geological engineering, $12 \%$ electromechanical engineering, $8 \%$ mining engineering, 7\% electronic engineering and the remaining $9 \%$ of the participants correspond to the other engineering programs offered by the "Universidad Pedagógica y Tecnológica de Colombia"

Continuing with the process to guarantee the quality of the data that was used for the estimation of parameters in the analysis of models of structural equations, an even stricter criterion was adopted when eliminating the respondents whose total response time of the survey was in $10 \%$ higher or lower of the entire sample. Considering this criterion and that some questionnaires would be invalid, they were applied in 315 , resulting in a total of 276 valid cases for the analysis, an acceptable value for a sample size representative of the population of interest. Once the data were purified, the distributions of all the items were examined. Asymmetry and kurtosis for all items were within the acceptable range of -2 to +2 . To verify the normal behavior of the data, histograms and graphs P-P and Q-Q were constructed and analyzed. No evidence was found to suggest any significant violation of the normality assumption. The outliers were also verified by means of box diagrams and this time, no outliers were found.

A confirmatory principal component analysis was performed to examine the fit of the measurement model of the entrepreneurial disposition. Correlation models and structural equations were used to examine the relationships of entrepreneurship disposition to entrepreneurial initiatives with leadership, creativity, the willingness to perform professionally as an employee, creativity and intelligence. In Table I, the results of the analysis of main components are presented where it is evident that the eigenvalues are associated to the number of factors that can explain the total variability of the data. This is how, for a factor (F1), the eigenvalue is 4.648 and explains a total of $42.251 \%$ of the variability of the data. For this research, it is decided to opt for a total of 5 factors (F5) that corresponds to an eigenvalue of 0.782 , providing an explanation of $84.063 \%$ of the total data. 
Table I. Partial results of the analysis of main components

\begin{tabular}{|c|c|c|c|c|c|c|c|}
\hline Number of factors & $\mathrm{Fl}$ & F2 & F3 & F4 & I5 & $\mathrm{F} 6$ & $\mathrm{~F} 7$ \\
\hline Onn value & 4,648 & 1,765 & 1,127 & 0,925 & 0,782 & 0,714 & 0,383 \\
\hline Variability (\%) & 42,251 & 16,043 & 10,247 & 8,412 & $7: 110$ & 6,490 & 3,484 \\
\hline \% accumulated & 42,251 & 58,294 & 68,540 & 76,953 & 84063 & 86,553 & 88,037 \\
\hline
\end{tabular}

The $\mathrm{R}^{\circledR}$ statistical software $\mathrm{w}$

as used to estimate structural equation models using the maximum likelihood estimation method. To evaluate the models, the recommendations of [30] were considered, in relation to the absolute adjustment indices should not be the only criterion to decide if a model is correct. As mentioned [31] the basis of statistical control is the understanding of natural variation in processes, which may be common or cause-specific. Therefore, a combination of relative adjustment indices was used, such as the Akaike information criterion (AIC) and the comparative adjustment index (CFI), and the absolute adjustment indices, such as the chi-square test (2) and the mean of the residual square root (SRMR), to assess whether the hypothetical model is a good fit to the observed data, similar to the Yin Chan study, and others, (2012). In general, sufficient statistical evidence was obtained to validate the construction of the measurement scales of the variables and of the initially proposed factors, insofar as the variables considered from the pilot study are grouped into these factors explaining a large percentage of the total variability of the data set.

With the identified factors, an analysis of linear correlations was made between the factor 1 , associated with the intention of the engineers to undertake entrepreneurial initiatives on their own, and the other factors. As expected, the intention to start a business on its own correlates negatively with the factor related to the intention to be employed in an organization and to continue training to improve their professional skills, the correlation index was -0.72 . On the other hand, sufficient statistical evidence was not obtained to affirm that there is any relationship between the intention to undertake a business initiative on its own account with the factors related to intelligence and creativity, the correlation indexes resulted in 0.15 and 0, 17 respectively. However, when analyzing the correlation between the personality variables grouped in one of the five factors identified and the disposition factor towards entrepreneurship, the evidence demonstrates a significant relationship.
Considering the importance of the personality factor of the engineer in the analysis of the disposition towards owning a micro or small company, by the engineers participating in the study, an analysis of the variables within this personality traits factor. When analyzing the descriptive statistics, specifically the arithmetic mean of the variables that were located as explanatory of the factor personality traits, can be highlighted as important to: 1) willingness to take risks; 2) not be afraid of failure; 3) self-confidence in skills and professional training and; 4) ability to identify opportunities in the environment. These elements of personality traits of the engineers participating in the study are added to the leadership characteristic that showed a Pearson correlation coefficient of 0.71 .

\section{Conclusions}

The profile of the students is very important for the education, in this sense, this research contributes from some practical perspective elements that can allow the "Universidad Pedagógica y Tecnológica de Colombia", to consider important elements of the profile of its students of last semester and graduates to the make curricular adjustments in the topic of entrepreneurship. In fact, in the global arena academic interest in entrepreneurship has increased over the last 50 years, so much so that it has come to be labeled "the most powerful economic force the world has ever experienced." [32]. In this sense, the results of this research show that, although $32 \%$ of the engineers state their willingness to have their own business, only $16 \%$ have carried out some activity in the field of entrepreneurship.

The statistical analysis of the main components made allows us to verify that the questions that make up the information collection tool are grouped into factors that reflect the intention of studying this research, such as the entrepreneur spirit of the engineers, their willingness to be employed, elements associated with creativity, leadership, to the intelligence and elements of personality traits. The analysis of the correlation between the resulting factors allows us to verify, according to the Pearson correlation coefficient, that there is no relationship between the entrepreneurial spirit and creativity or intelligence. In contrast, the factor associated with the entrepreneurial spirit was negatively correlated with the factor associated with the willingness of engineers to develop their professional activity as employees. These findings allow to verify for this case study, the statements of [3]. 
Finally, the factor associated with the entrepreneurial spirit correlated positively with the leadership factor, with a Pearson correlation coefficient of 0.71 . This finding opens the doors to study more carefully, for this case study, the proposals of [12] in the sense that entrepreneurship is a form of leadership. In this same direction, the factor associated with entrepreneurial spirit had a correlation coefficient of 0.73 with the factor that includes variables associated with personality traits of the engineer. Once the leadership has been identified as a factor that influences the entrepreneurial spirit, by analyzing the interior of the factor associated with the variables of personality traits, it was possible to compare that the most valued items correspond to: 1) willingness to take risks; 2) not be afraid of failure; 3) self-confidence in skills and professional training and; 4) ability to identify opportunities in the environment.

\section{Acknowledgments}

The team members of this research express their gratitude to the students and graduates of the engineering programs of the "Universidad Pedagógica y Tecnológica de Colombia" for their participation and willingness to provide reliable data for the conduct of this study. Likewise, to the different dependencies of this university that provided valuable information when identifying and contacting the members of the sample of engineers participating in the study.

\section{References}

[1] R. Kanter, "Careers and the wealth of nations: A macro-perspective on the structure and implications of career forms.", de Handbook of career theory, Cambridge, UK, Cambridge University Press, pp. 506-522, 1989.

[2] E. Schein, "Career dynamics. Reading", $M A$ : Addison-Wesley, 1978.

[3] T. Antonio, S. Lanawati, T. Wiriana and L. Christina, "Correlations Creativity, Intelligence, Personality, and Entrepreneurship Achievement", Procedia - Social and Behavioral Sciences, vol. 115, pp. 251-257, 2014.
[4] G. McElwee, "Farmers as entrepreneurs: developing competitive skills", Journal of Developmental Entrepreneurship, vol. 11, no. 3, p. 187-206, 2006.

[5] V. Gupta, . I. C. MacMillan and G. Surie, "Entrepreneurial leadership: developing and measuring a cross-cultural construct", Journal of Business Venturing, vol. 19, pp. 241-260, 2004.

[6] M. Kets de Vries, "The entrepreneurial personality", Journal of Management Studies, vol. 14, pp. 34-57, 1977.

[7] D. Miller, "The correlates of entrepreneurship in three types of firms", Management Science, vol. 29, pp. 770-791, 1983.

[8] G. Lumpkin and G. Dess, "Clarifying the entrepreneurial orientation construct and linking it to performance", Academy of Management, vol. 21, no. 1, pp. 135-172, 1996.

[9] J. Silva, "Emprendedor - Crear su propia empresa”, Bogotá: Editorial Alfaomega, 2008.

[10] R. Zarate-Torres, D. Arguelles-Pabón, S. Aparicio, C. Salcedo, A. Ibarra, F. Matiz, L. Parra and M. Argote, "Emprendimiento. Diferentes aproximaciones", Cuaderno de investigación, Bogotá: Ed. Universidad EAN, 2013.

[11] R. Kanter, "The middle manager as innovator", Harvard Business Review, vol. 60, no. 4, pp. 95-105, 1982.

[12] R. Vecchio, "Entrepreneurship and leadership: common trends and common threads", Human Resource Management Review, vol. 13, no. 2, pp. 303-327, 2003.

[13] W. Stewart and P. Roth, "Risk propensity differences between entrepreneurs and managers: A meta-analytic review", Journal of Applied Psychology, vol. 86, no. 1, pp. 145-153, 2001. 
[14] S. Lanawati, "Pengaruh Intelegensi, Kreativitas, Kecerdasan Emosional dan Khepri badian terhadap Prestasi Akademik Mahasiswa", Disertasi:Universitas Indonesia", pp. 251-257, 2005.

[15] C. Ramos, A. Campillo and R. Gago, "Características del emprendedor influyentes en el proceso de creación empresarial y en el éxito esperado/The features of entrepreneurs influencing business creation and success expectancy", Revista Europea de dirección y economía de la empresa, vol. 19, no. 2, pp. 3147, 2010.

[16] H. Kantis, P. Angelelli and F. Gatto, "Nuevos emprendimientos y emprendedores en Argentina: ¿de qué depende su creación y supervivencia?”, Las pequeñas y medianas empresas: entorno, estrategias y potencial transformador", Memorias de la VReunión Anual de la Red PyMEs Mercosur, Cordoba, 2000.

[17] I. Kirzner, "Perception, Opportunity and Profit", Chicago: University of Chicago Press, 1979.

[18] J. Veciana, "Creación de empresas como programa de investigación científica", Revista Europea de Dirección y Economía de la Empresa, vol. 8, no. 3, pp. 11-36, 1999.

[19] D. C. McClelland, "The achieving society", Princeton. N.J.: D. Van, 1961.

[20] M. Minniti and W. Bygrave, "A Dynamic Model of Entrepreneurial Learning”, Entrepreneurship Theory and Practice, vol. 25, no. 3, p. 5-16, 2001.

[21] . A. Lundstrom and L. A. Stevenson, "Entrepreneurship Policy: Theory and Practice", London: Springer, 2005.
[22] H. Brandstätter, "Becoming an entrepreneur - A question of personality structure?", Journal of Economic Psychology, vol. 18, no. 2-3, pp. 157-177, 1997.

[23] R. Molina Sánchez, A. López and C. Schimtt, "Factores Que Influyen en los Problemas del Emprendimiento de las Mipymes: Una Percepción de los Expertos", Revista internacional de administración y finanzas, vol. 9, no. 1, pp. 95-113, 2016.

[24] F. Leutner, G. Ahmetoglu, R. Akhtar and T. Chamorro-Premuzic, "The relationship between the entrepreneurial personality and the Big Five personality traits", Personality and Individual Differences, pp. 58-63, 2014.

[25] Z. Zhang, . M. J. Zyphur, J. Narayanan, R. D. Arvey, S. Chaturvedi, B. J. Avo, P. Lichtenstein and G. Larsson, "The genetic basis of entrepreneurship: Effects of gender and personality", Organizational Behavior and Human Decision Processes, pp. 93-107, 2009.

[26] S. Alvarez and L. Busenitz, "The entrepreneurship of resource-based theory", Journal of Management, vol. 27, no. 6, p. 755$775,2001$.

[27] W. Gartner, "What are we talking about when we talk about entrepreneurship?", Journal of Business Venturing, vol. 5, no. 1, pp. 15-28, 1990.

[28] R. Hernández Sampieri, C. Fernández Collado and P. Baptista Lucio, "Metodología de la investigación", México: McGraw Hill, 2006.

[29] K. Yin Chan, M.-h. R. Ho, O. S. Cherny, O. Bedford, M. A. Uy, D. Gomulya, Y. Sam and W. Phan, "Entrepreneurship, professionalism, leadership: A framework and measure for understanding boundaryless careers", Journal of Vocational Behavior, pp. 73-88, 2012. 
[30] M. Spiegel and L. Stephens, "Estadística, 6a edición ed.", Ciudad de México: Mc Graw-Hill, 2015.

[31] Y. C. Ortiz González y I. M. González Gaitán, "Control estadístico de procesos en organizaciones del sector servicios", Respuestas, vol. 23, no. S1, pp. 42-49, 2018

[32] D. Iacobucci, "Structural equation modeling: Fit indices, sample size, and advanced topics", Journal of Consumer Psychology, pp. 90-98, 2010 . 